\title{
Menumbuhkembangkan Kepedulian Siswa Terhadap Lingkungan Melalui Kegiatan Penghijauan di MIM Pakang Andong, Boyolali
}

\author{
Abdillah Nugroho ${ }^{1}$, Ayu Fatonah ${ }^{2}$, Dwi Putra Enggar Wijaya ${ }^{3}$, Rinanda Prakarsa Putri ${ }^{4}$, Muhammad \\ Nurul Fikri ${ }^{5}$, Oki Setiawan ${ }^{6}$ Lastika Yuly Kurniawan $^{7}$, Juwari Septi Astuti ${ }^{8}$, Febi Tria Primandika ${ }^{9}$, \\ Sischa Aprilya Chyntia Budiarti ${ }^{10}$

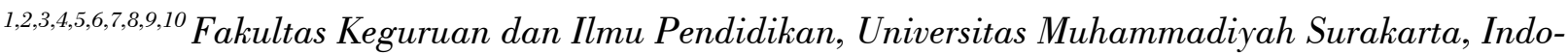 \\ nesia
}

\section{INFORMASI ARTIKEL}

\section{Histori Artikel:}

Submit: 18 Mei 2020

Revisi: 1 Juni 2020

Diterima: 25 Juni 2020

Publikasi: 30 Juni 2020

Periode Terbit: Juli 2020

\section{Kata Kunci:}

kepedulian,

lingkungan,

penghijauan

\section{Correspondent Author:}

Ayu Fatonah

Fakultas Keguruan dan Ilmu Pendidikan

Universitas Muhammadiyah Surakarta,

Indonesia

Email:

a610160097@student.ums.ac.id

\begin{abstract}
ABSTRAK
Kondisi lingkungan setiap tahunnya semakin memprihatinkan. Manusia semakin tidak peduli dengan lingkungan, sehingga kerusakan lingkungan terjadi dimana-mana. Banyaknya kerusakan lingkungan akibat dari ulah manusia diantaranya pembalakan hutan secara liar dan pembuangan sampah. Kepedulian terhadap lingkungan harus ditanamkan sejak dini agar kesadaran akan menjaga lingkungan sekitar tertanam sehingga kerusakan lingkungan dapat terkurangi. Tujuan pelaksanan pengabdian ini adalah menumbuhkan kepedulian siswa terhadap lingkungan melalui kegiatan penghijauan di MIM Pakang, Andong. Metode pelaksanaan pengabdian ini yaitu dengan pendidikan masyarakat melalui kegiatan penyuluhan warga sekolah terutama kepada siswa. Upaya dalam menumbuhkan kepedulian siswa terhadap lingkungan di MIM Pakang, Andong yaitu melalui kegiatan penghijauan. Kegiatan penghijauan yang dilakukan yaitu berupa menanam pohon cemara dan pembuatan taman dengan menggunakan barang bekas sebagai pot. Kepedulian siswa terhadap lingkungan baik ditunjukkan dengan siswa mengikuti semua kegiatan yang diarahkan oleh mahasiswa KKN-DIK dengan antusias yang tinggi.
\end{abstract}

\section{Pendahuluan}

Lingkungan menjadi tempat berlangsungnya kehidupan antar mahluk hidup tanpa terkecuali manusia. Kondisi lingkungan yang ada setiap tahunnya mengalami penurunan. Permasalahan tentang lingkungan menjadi ancaman yang tiada hentinya. Kerusakan lingkungan sebagian besar disebabkan oleh perilaku manusia. Banyak kerusakan lingkungan yang terjadi di Indonesia diantaranya pembalakan liar dan penggunaan sumber daya alam yang secara berlebihan, tanpa ada konservasi yang berkelanjutan (Narut \& Nardi, 2019). Luas hutan di Indonesia Menurut Kementerian Lingkungan Hidup dan Kehutanan pada tahun 2017 menjadi 125,9 juta hektare, yang telah mengalami penurunan dari tahun 2015 dengan luas hutan yaitu 128 juta hektare.

Selain terdegradasinya luas hutan, permasalahan lingkungan yang lain yaitu permasalahan sampah. Indonesia menjadi negara penghasil sampah plastik terbanyak kedua di dunia. Pada tahun 2017, jumlah sampah di Indonesia yaitu 64 juta ton per tahun dengan jumlah sam- 


\section{doi: 10.23917/bkkndik.v2i1.10786}

pah plastik sebanyak 15\% (Fajrian, 2019). Banyak kerusakan lingkungan yang diakibatkan dari sampah ini. Sampah yang tidak di olah secara baik akan berdampak pada tercemarnya lingkungan, terganggunya kehidupan mahluk lain serta dapat menimbulkan bencana alam salah satunya bencana banjir (Harahap, 2016). Berdasarkan permasalahan tersebut, menumbuhkan kesadaran dan kepedulian masyarakat terhadap lingkungan sekitar sangat penting.

Peduli lingkungan merupakan sikap dan tindakan yang selalu diupayakan untuk mencegah kerusakan lingkungan sekitarnya dan menumbuhkan upaya-upaya untuk memperbaiki kerusakan alam yang sudah terjadi Asmani (dalam Narut, 2019). Sikap peduli lingkungan hendaknya ditanamkan sejak dini sebagai generasi masa depan yang menjadi agen perubahan. Penanaman sikap peduli lingkungan dapat dilakukan di sekolah terutama pada siswa sekolah dasar. Siswa yang pada dasarnya sedang mengalami pola pikir, bisa diajak serta dibiasakan untuk mengenali dan menyadari pentingnya nilai peduli lingkungan sejak dini (Idrus \& Novia, 2018). Oleh karenanya, pemerintah melalui Balai Lingkungan Hidup bekerjasama dengan sekolah mengadakan program pendidikan lingkungan hidup atau program Adiwiyata. Tujuan program Adiwiyata adalah mewujudkan warga sekolah yang bertanggung jawab terhadap perlindungan dan pengelolaan lingkungan hidup melalui tata kelola sekolah yang baik. Program ini dimaksudkan untuk mendukung upaya pembangunan berkelanjutan di Indonesia. Tidak semua sekolah mengikuti program ini karena dibutuhkan komitmen yang tinggi dalam menerapkan pendidikan lingkungan hidup dalam aktivitas di sekolah (Purwiastuti, 2019).

Penataan lingkungan sekolah menjadi GreenSchool merupakan penataan lingkungan sekolah sehingga dapat menciptakan suasana yang asri, sejuk, bersih, sehat dan dapat mendukung proses pelaksanaan KBM. Lingkungan sekolah yang kondusif sangat di perlukan dalam menghasilkan proses belajar yang nyaman. Lingkungan sekolah yang kondusif akan ikut mendorong terwujudnya pola hidup bermutu yang saat ini sangat diperlukan dalam meningkatkan produktivitas pendidikan (Ratih, et al., 2019).

Kegiatan yang dapat dilakukan dalam menumbuhkan kepedulian siswa terhadap lingkungan, yaitu melalui kegiatan penghijauan dan pengelolaan sampah. Penghijauan adalah segala upaya untuk memulihkan, memelihara dan meningkatkan kondisi lahan agar dapat berproduksi dan berfungsi secara optimal, baik pengatur tata air atau pelindung lingkungan (Mardiani, 2017). Penghijauan menjadi salah satu kegiatan yang dapat menangani kerusakan lingkungan. Jadi, penghijauan adalah kegiatan penanaman pada lahan kosong di luar kawasan hutan serta pembuatan bangunan pencegah erosi tanah dengan tujuan agar lahan tersebut dapat dipulihkan, dipertahankan, dan ditingkatkan kembali kesuburannya (Setiawan, 2019).

Selain itu, upaya dalam mengurangi kerusakan lingkungan juga dapat dilakukan dengan melakukan pengeloaan sampah. Pengelolaan sampah merupakan salah satu pembiasaan yang dapat dilakukan untuk menanamkan sikap peduli terhadap lingkungan, yaitu dengan mengajak siswa untuk mengelola sampah berbasis 3R (Reduce, Reuse, Recycle) (Arisona, 2018; Setyadi, Anggrahini, Putri, \& Wardani, 2019).

Mahasiswa KKN-Dik FKIP UMS melaksanakan pengabdian yang berlokasi di MIM Pakang, Andong, Boyolali. Kondisi MIM Pakang, Andong yang menjadi lokasi pengabdian merupakan sekolah yang cukup memprihatinkan kondisi lingkungannya. Hasil observasi yang dilakukan oleh mahasiswa, MIM Pakang kurang memperhatikan kondisi tanaman dan juga pengelolaan sampah. Pada lingkungan sekolah tersebut juga terdapat lahan yang tidak dimanfaatkan dengan baik dan dibiarkan sebagai tempat sampah yang tidak terawat.

Berdasarkan permasalahan yang ada di MIM Pakang tersebut, maka mahasiswa KKN-Dik FKIP UMS bertujuan melakukan penghijauan berupa penanaman pohon dan pembuatan taman dengan menggunakan barang bekas sebagai pot tanaman. Berdasarkan uraian permasalahan tersebut, mahasiswa KKN-Dik FKIP UMS melaksanakan pengabdian kepada sekolah dengan kegiatan berupa Menumbuhkan Kepedulian Siswa terhadap Lingkungan melalui Kegiatan Penghijauan di MIM Pakang Andong.

\section{Metode Pelaksanaan}

Upaya dalam menyelesaikan permasalahan lingkungan yang ada di MIM pakang Andong dapat dilakukan dengan cara menumbuhkan sikap peduli lingkungan melalui kegiatan penghijauan. Pelaksanaan pengabdian ini menggunakan metode pendidikan masyarakat. Metode pelaksanaan pengabdian dilakukan dengan cara melakukan penyuluhan kepada warga sekolah terutama 
kepada siswa. Penyuluhan dilakukan dengan cara melibatkan siswa secara langsung dalam kegiatan penghijauan disertai dengan penjelasan tentang pentingnya melakukan penghijauan. Siswa diajak untuk terlibat dalam menyelesaikan permasalahan lingkungan di sekolah mereka dengan cara melakukan penanaman pohon cemara, pembuatan taman serta mendaur ulang botol dan ban bekas menjadi pot tanaman. Kegiatan ini dilakukan sebagai upaya dalam menumbuhkan kesadaran siswa tentang pentingnya kepedulian terhadap lingkungan.

\section{Hasil Pelaksanaan dan Pembahasan}

KKN-Dik FKIP UMS merupakan program kurikuler wajib bagi seluruh mahasiswa (S1). KKN-Dik merupakan salah satu bentuk kegiatan yang memberikan pengalaman belajar kepada mahasiswa di tengah-tengah kehidupan bermasyarakat di luar kampus. Kegiatan KKN-Dik memiliki tujuan untuk membantu masyarakat, terutama masyarakat daerah tertinggal dan juga menyelesaikan permasalahan yang dihadapi. Kegiatan ini juga sebagai wahana bagi mahasiswa untuk mengaplikasikan teori-teori yang telah diperoleh di perguruan tinggi dalam sebuah wujud nyata berupa pengabdian kepada masyarakat.

FKIP UMS dalam melaksanakan kegiatan KKNDik dengan menerjunkan mahasiswa ke berbagai daerah yang tertinggal terutama sekolah-sekolah yang belum maju. Salah satu lokasi yang menjadi tempat berlangsungnya KKN-Dik, yaitu MIM Pakang Kecamatan Andong Kabupaten Boyolali. Kegiatan berupa program kerja telah disusun oleh mahasiswa untuk menumbuhkan sekolah menjadi lebih baik lagi.

Pelaksanaan KKN-Dik sebelum melakukan program kerja yang akan dilakukan sebagai bentuk pengabdian, yaitu para mahasiswa melakukan observasi untuk mengetahui permasalahan-permasalahan yang ada di tempat pengabdian. Hasil observasi yang dilakukan oleh mahasiswa ditemukan beberapa permasalahan diantaranya yaitu sekolah kurang memperhatikan tanaman, lahan kosong serta pemanfaatan sampah atau barang bekas. Melihat kondisi tersebut, kemudian mahasiswa membuat program kerja berupa penghijauan berupa penanaman pohon cemara dan pembuatan taman dengan memanfaatkan barang bekas sebagai pot tanaman.

Penghijauan merupakan salah kegiatan yang dapat mengembangkan sikap peduli siswa terhadap lingkungan sekitar mereka tinggal. Hal ini sesuai dengan hasil penelitian yang dilakukan oleh Mardiani (2017), yang menunjukkan bahwa pelaksanaan kegiatan penghijauan dapat meningkatkan kepedulian siswa terhadap lingkungan. Pengembangan sikap peduli siswa di MIM Pakang, salah satunya dilakukan dengan melakukan penghijauan. Penghijauan di sekolah ini dilaksanakan dengan menanam pohon cemara di beberapa tempat atau halaman sekolah yang telah ditentukan. Kegiatan penanaman pohon cemara di MIM Pakang, Andong dapat dilihat pada gambar 1 .

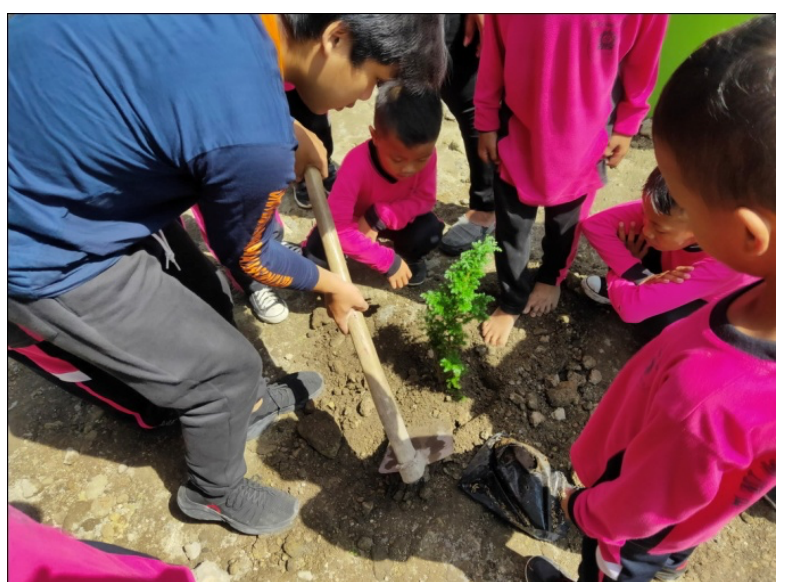

Gambar 1. Pelaksanaan Penanaman Pohon Cemara

Penghijauan sebagai bentuk kepedulian dalam bentuk kegiatan spontan yang dapat dilakukan oleh siswa secara tiba-tiba. Kegiatan spontan berupa penanaman pohon secara bersama merupakan bentuk pelaksanaan nilai peduli lingkungan (Idrus, 2018). Penanaman nilai ini, diharapkan siswa mengetahui bahwa kegiatan menanam pohon itu penting. Kegiatan penghijauan adalah salah bentuk dalam menanggulangi terjadinya bencana alam yaitu bencana banjir dan bencana tanah longsor, sehingga dengan kegiatan ini siswa secara tidak langsung ikut berperan dalam mitigasi bencana. Kegiatan ini dilakukan juga dimaksudkan agar siswa mengetahui bahwa dengan melakukan penghijau dapat memberi banyak manfaat, diantaranya yaitu memperbaiki kondisi lahan yang sudah rusak, memperbanyak persediaan oksigen dan sebagai sumber cadangan air dalam tanah.

Salah satu bentuk kegiatan penghijauan yang dilakukan di MIM Pakang, Andong, yaitu pembuatan taman. Pembuatan taman dilakukan karena melihat kondisi sekolah yang membiarkan lahan kosong yang tidak digunakan dengan sebaik mungkin. Kondisi lahan tersebut dapat dilihat pada gambar 2. Lahan berdasarkan 


\section{doi: 10.23917/bkkndik.v2i1.10786}

gambar tersebut digunakan sebagai tempat sampah yang tidak terawat. Banyak sampah berserakan, bebatuan yang terlihat tidak beraturan sehingga mengganggu pemandangan. Berdasarkan hal tersebut, mahasiswa dibantu dengan guru dan siswa mengubah tempat tersebut menjadi sebuah taman.

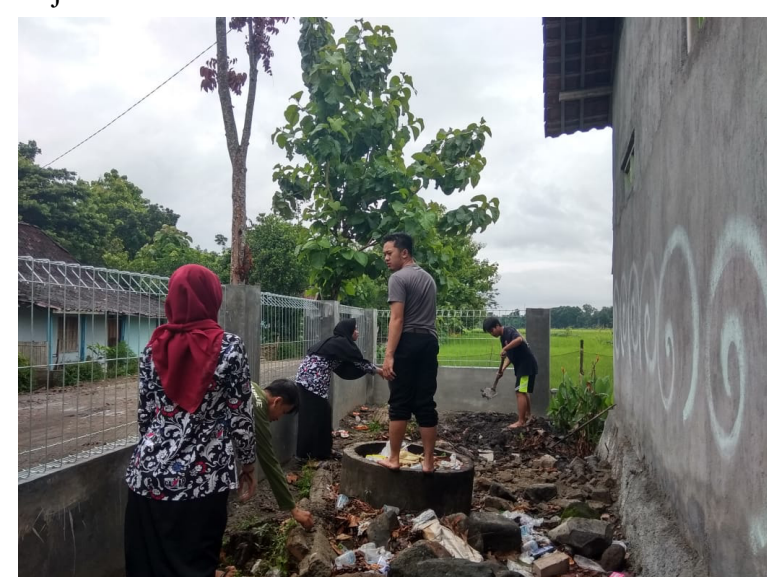

Gambar 2. Kondisi Lahan Sebelum dibuat Taman

Pelaksanaan dalam membuat taman dilaksanakan secara bertahap, kegiatan tersebut berupa pengerukan lahan, pengecatan tembok, kemudian melakukan penanaman dengan media barang bekas (botol dan ban bekas). Pembuatan taman menjadi salah satu program kerja besar yang dilaksanakan oleh mahasiswa KKN-Dik MIM Pakang, sehingga memerlukan waktu yang cukup lama. Tahap pertama dalam pembuatan taman yaitu melakukan pengerukan lahan kosong tersebut yang sebelumnya telah dibersihkan sampah dan bebatuan tersebut oleh mahasiswa. Kegiatan pengerukan dilaksanakan dengan cara gotong royong oleh guru, siswa dan mahasiswa KKN-Dik. Kegiatan ini sebagai salah bentuk sikap peduli dengan cara melakukan pekerjaan secara bersama-sama agar mudah dan cepat selesai. Kegiatan gotong royong dalam melakukan pengerukan dapat dilihat pada gambar 3 . Berdasarkan gambar dapat dilihat siswa begitu antusias mengikuti kegiatan demi kegiatan sebagai bentuk sikap peduli terhadap lingkungan.

Kegiatan selanjutnya dalam pembuatan taman yaitu melakukan pengecatan tembok. Pengecatan tembok dilakukan oleh mahasiswa KKN-Dik. Kegiatan tersebut juga dibarengi dengan pembuatan pot dari botol dan ban bekas. Pembuatan pot ini bertujuan sebagai salah satu sikap peduli siswa dengan memanfaatkan sampah yang dapat di daur ulang diantaranya yaitu botol dan ban bekas. Hal ini sesuai dengan penelitian yang dilakukan
Mertha et al, (2018) dengan hasil penelitian bahwa kegiatan memilah sampah kemudian memanfaatkan sampah menjadi bahan yang bisa dipakai kembali. Selain itu, hasil penelitian yang dilakukan Kurniati et al., (2019) menunjukkan bahwa kegiatan memilah sampah merupakan upaya yang dilakukan untuk menanamkan kepedulian anak terhadap lingkungan sekitar. Penggunaan botol dan ban bekas ini diharapkan menjadi salah satu pembelajaran penting bagi siswa agar peduli dengan lingkungan sekitar tempat mereka tinggal. Berkurangnya sampah sehingga mampu untuk mengurangi kerusakan lingkungan salah satunya yaitu pencemaran lingkungan akibat sampah.

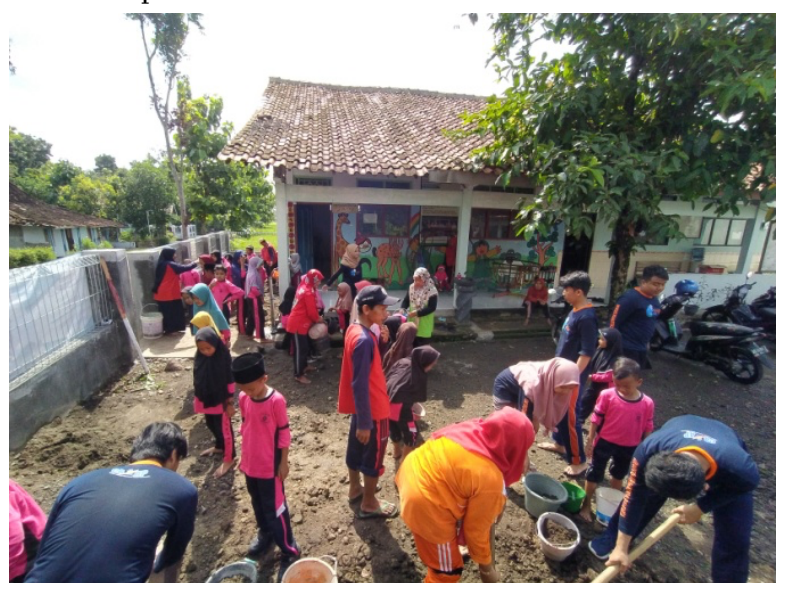

Gambar 3. Kegiatan Pengurukan Lahan Kosong

Pembuatan pot dari botol dan bekas ini dilakukan oleh mahasiswa KKN-Dik FKIP UMS bersama dengan siswa MIM Pakang. Botol bekas yang telah dibawa oleh siswa kemudian diubah menjadi pot oleh mahasiswa, kemudian botol-botol yang telah dibentuk menjadi pot diwarnai agar terlihat menarik dan enak dipandang. Selain itu, ban bekas juga diwarnai agar tidak terlihat monoton dan lebih menarik.

Tahap selanjutnya yaitu menanam tanaman berupa bunga dan pohon cemara di taman dengan menggunakan pot dari barang bekas. Tanaman yang akan ditanam adalah tanaman yang dibawa oleh siswa dari rumah. Selain itu, mahasiswa juga ikut menyumbang beberapa tanaman berupa bunga untuk ditanam. Penanaman bunga ke dalam pot yang terbuat dari barang bekas tersebut dilakukan oleh mahasiswa yang dibantu oleh siswa (lihat gambar 4). Antusias siswa sangat tinggi dalam melaksanakan kegiatan ini. Botol yang telah ditanam sebagian digantung dinding dan sebagian digantung di pagar. 


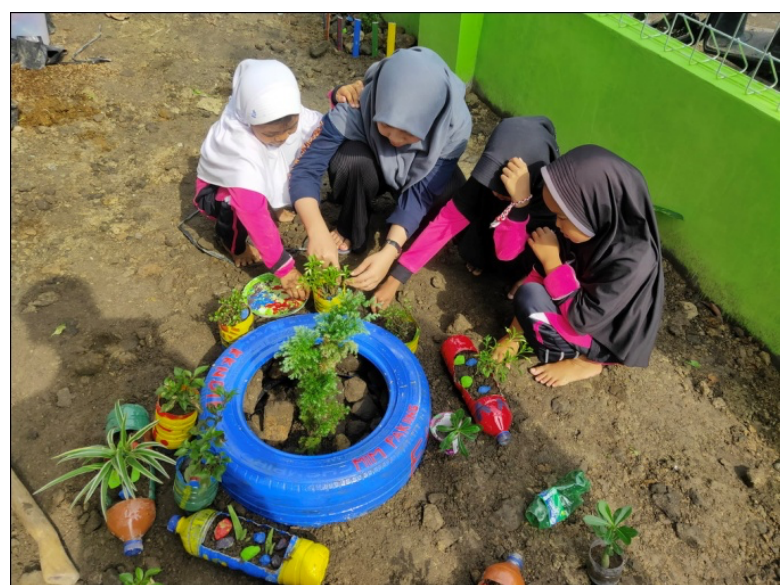

Gambar 4. Penanaman Bunga dan Pohon di Taman

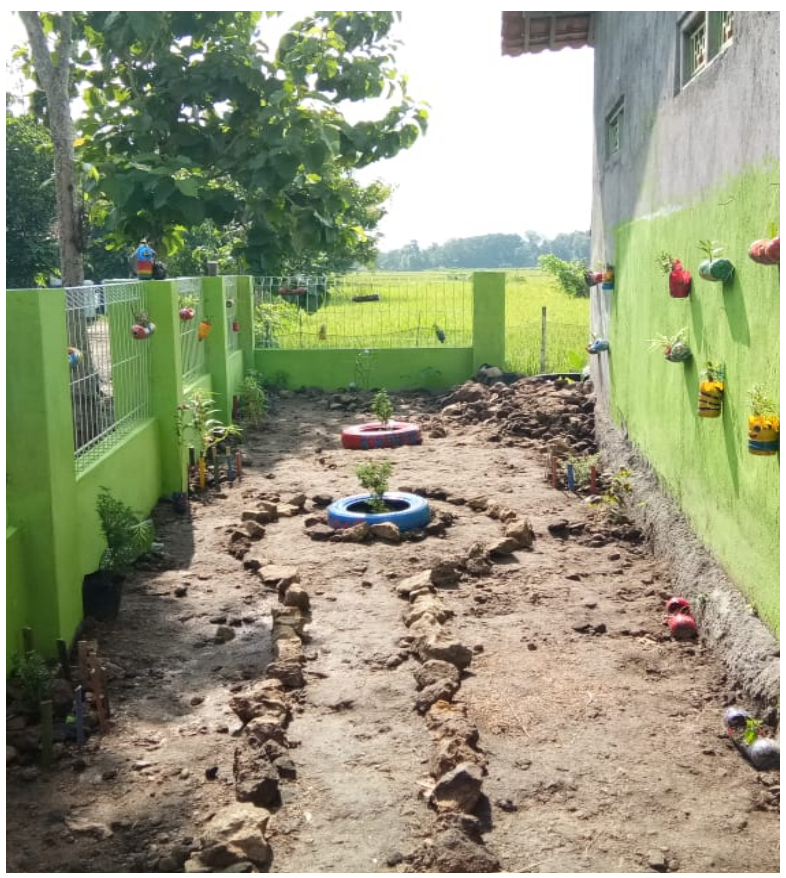

Gambar 5. Hasil Akhir Pembuatan Taman

Gambar 5 tersebut adalah bentuk dari taman yang telah dibuat. Perawatan berkelanjutan oleh siswa dan guru sangat diperlukan agar taman tersebut dapat hidup dan lebih indah di kemudian hari. Kegiatan penghijauan berupa penanaman pohon cemara dan pembuatan taman dengan memanfaatkan barang bekas adalah salah satu program kerja yang dilakukan oleh mahasiswa KKN-Dik FKIP UMS untuk menanamkan kesadaran dan sikap peduli terhadap lingkungan sekitar siswa. Kegiatan yang dilakukan dengan mengikutsertakan siswa secara langsung memiliki tujuan agar siswa dengan mudah me- mahami bahwa peduli dengan lingkungan itu penting bagi keberlangsungan hidup semua mahluk.

\section{Simpulan}

Upaya dalam menumbuhkan sikap siswa MIM Pakang terhadap lingkungan yaitu dengan melakukan kegiatan penghijauan. Kegiatan penghijauan merupakan program kerja yang dilaksanakan oleh mahasiswa KKNDik FKIP UMS yang berlokasi di MIM Pakang, Andong. Kegiatan penghijauan dilakukan dengan menanam pohon cemara dan pembuatan taman dengan memanfaatkan botol dan ban bekas sebagai pot. Siswa menunjukkan sikap peduli lingkungan yang baik dengan mengikuti setiap kegiatan yang diarahkan oleh mahasiswa dan menunjukkan sikap antusias yang sangat tinggi. Hal tersebut dapat menjadi pendorong para pemangku kepentingan di MIM Muhammadiyah Pakang Andong Boyolali menjadikan sekolah mereka sebagai green school.

\section{Daftar Pustaka}

Arisona, R. D. (2018). Pengelolaan Sampah 3r (Reduce, Reuse, Recycle) pada Pembelajaran IPS untuk Menumbuhkan Karakter Peduli Lingkungan. Al Ulya, 3(I), 39-5l.

Harahap, R. D. (2016). Pengaruh Sampah Rumah Tangga Terhadap Pelestarian Lingkungan ditinjau dari Aspek Biologi di Komplek Perumahan Graha Pertiwi Kel. Urung Kompas Kec. Rantau Selatan Effect of Household Waste Viewed from The Aspect Environmental Conservation Biology in Housing Complex Graha Pertiwi Kel. Undo Kompas Kec. South Rantau. Cahaya Pendidikan, 2(1).

Idrus, A., \& Novia, Y. (2018). Pelaksanaan Nilai Peduli Lingkungan Di Sekolah Dasar. Jurnal Gentala Pendidikan Dasar, 3(2), 203-219.

Kurniati, E., Mirawati, M., Rudiyanto, R., Fitriani, A. D., Rengganis, I., \& Justicia, R. (2019). Implementasi Program Anak Peduli Lingkungan Melalui Kegiatan Memilah Sampah. Early Childhood: Jurnal Pendidikan, 3(1), 1-6.

Mardiani, W. (2017). Pelaksanaan Kegiatan Penghijauan Untuk Meningkatkan Kepedulian Siswa Terhadap Lingkungan Di SDN 112 Pekanbaru. Suara Guru, 3(2), 289-298.

Mertha, I. G., Al Idrus, A., Ilhamdi, M. L., \& Zulkifli, L. (2018). Pelatihan Teknik Pembuatan Herbarium Kering dan identifikasi tumbuhan berbasis lingkungan sekolah di SMAN 4 Mataram. Jurnal Pendidikan Dan Pengabdian Masyarakat, 1(1).

Narut, Y. F., \& Nardi, M. (2019). Analisis Sikap Peduli 
Lingkungan Pada Siswa Kelas VI Sekolah Dasar di Kota Ruteng. Scholaria: Jurnal Pendidikan Dan Kebudayaan, 9(3), 259-266.

Ratih, K., Prayitno, H. J., Sutopo, A., Tamatea, L., \& Syahriandi, M. (2019). Preparing for Quality EFL Teachers: The Disjuncture Between Policies and Practice in The Internet Communication Technology (ICT) Use in Classroom Context.

Setyadi, Y. B., Anggrahini, T. O., Putri, N., \& Wardani, K. (2019). Penerapan Budaya $5 S$ sebagai Penguatan Pendidikan Karakter Siswa di MTs Muhammadiyah 9 Mondokan, Sragen. 1(2), 7076. https://doi.org/10.23917/bkkndik.vli2.10774 